\title{
The Influence of Food Service Quality and Innovation Production on Local Product of Thailand: Study of Creative Agriculture
}

\author{
Waleerak Sittisom ${ }^{1} \&$ Thammarak Srimarut ${ }^{1}$ \\ ${ }^{1}$ Suan Sunandha Rajabhat University, Bangkok, Thailand \\ Correspondence: Waleerak Sittisom, Suan Sunandha Rajabhat University, Bangkok, Thailand. E-mail: \\ waleerak.si@ssru.ac.th
}

Received: July 17, 2020

Accepted: September 4, 2020

Online Published: September 28, 2020

doi:10.5430/rwe.v11n5p469

URL: https://doi.org/10.5430/rwe.v11n5p469

\begin{abstract}
Creative agriculture is a vast and deep knowledge of a product from its preparation from raw material to the end consumer of the product. Hence creative agriculture deals with deep analysis, production process, and commercialization, of a product. The present study explored the relationship between food service quality, innovation in production, customers' satisfaction, and local product promotion. Both the foodservice quality and innovation in production increase customer satisfaction and local product promotion. An increased level of customer satisfaction is also promising for the increment in local product promotion. A survey from 300 food engineers working with different food providing companies, were the respondents of the present study for the collection of primary data. Then, a statistical software, named Partial Least Square (PLS) was used for the finalization of the data analysis process. The results achieved from the data analysis were used for the accomplishment of the end results of the present study.
\end{abstract}

Keywords: foodservice quality, innovation in production, customer satisfaction, local product promotion

\section{Introduction}

A rapid change in the agriculture sector has brought some significant changes that have transformed routine agriculture into creative agriculture ( $\mathrm{Li}$ et al., 2020). Creative agriculture is about to create new products based on harvested crops used as a raw material (Debnath, 2020). In the world of today where the demand for food is increasing very rapidly, innovation for new products based on already available natural food such as fruits and vegetables is also increasing to meet the demand and for the satisfaction of consumers of food companies. Innovative products are mandatory not only for the business of food supplying companies but also to meet the increased volume of demand for food.

The food sector of Thailand fulfills the foody needs of its population. In most countries, food supplying companies make foods and supply it at the doorstep of the end consumers of those foods (Rampa, Lammers, Linnemann, Schoustra, \& de Winter, 2020). World's famous food companies are also working in Thailand for business perspectives and to meet Thai people's foods need and satisfaction. Therefore, better quality with a delicious taste of food production is important. Production of new innovative foods helps to capture new consumers hence it also causes enormous profit for food production companies. Following Figure 1 shows the foodservice market volume estimated until 2022 in Thailand. 


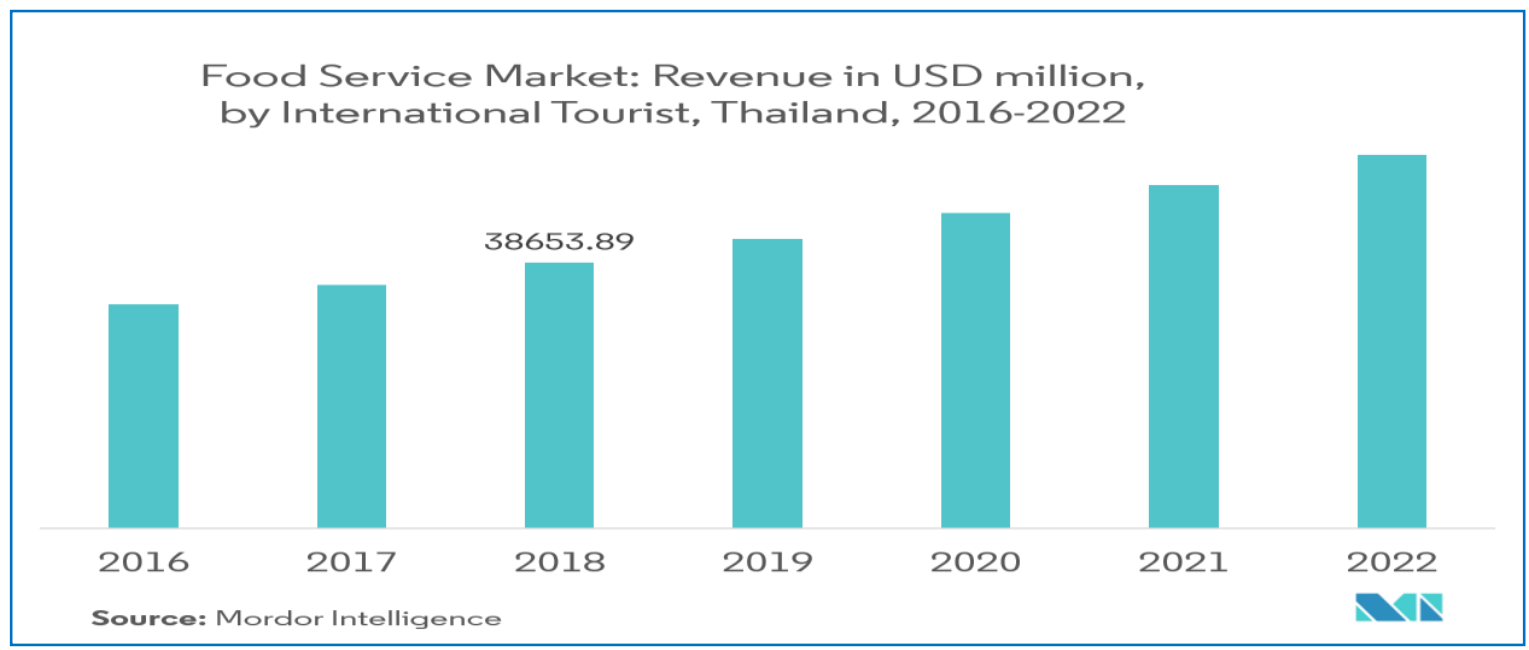

Figure 1. Foodservice market in Thailand

Source: Mordor Intelligence

Local products of Thailand are not sufficient to meet the required demand for food for their people. Moreover, local products of Thailand are not available at a quality level that is expected from the consumers. It is noticed that available food service quality needs more attention to the popularity of the local products among the people of the country. Because quality-less food or food with low quality never satisfy its end consumer (Burani \& Mantovani, 2020). Furthermore, there is a need for the creation of an innovative product based on already available natural material mixed with biochemical. According to the present study, foodservice quality and innovation in production have significant impacts on customer satisfaction and local product promotion.

Previous studies have explored the relationship between foodservice quality and customer satisfaction however, they have amazingly missed the role of innovation in production with the relation of foodservice quality (Saad, AbuKhalifeh, Slamat, \& TengkuYacob, 2020). Hence, the present study has illustrated the relationship between foodservice quality, innovation in production, customer satisfaction, and local product promotion. In previous literature, the relationship between current variables of the present study is missing particularly for Thailand's local food product promotion. Therefore, the present study is a vital contribution to the body of literature.

The major objective of the present study is to evaluate how different factors of a creative agriculture system can be utilized by food providing companies to earn their customers' satisfaction. And with the help of earned customers' satisfaction how these companies can utilize these factors for their local product promotion. Moreover, the present study deals with the food companies available in Thailand. Furthermore, customer satisfaction has significant impacts on local product promotion produced by food companies. Hence, food service quality and innovation in the product are the two major factors that have a direct impact on customer satisfaction and an indirect impact on local product promotion. Therefore, the core purpose of the present study is to investigate the role of foodservice quality, innovation in production for food companies, particularly in Thailand.

The present study has explored the relationship between foodservice quality, innovation in production, customers' satisfaction, and local product promotion. Hence, the present study has a crucial contribution to the literature. Moreover, the present study has both theoretical and practical contributions to the literature. Theoretically, this study describes the relationship between food service quality, innovation in production, customer satisfaction, and local product promotion. Practically the present study helps the practitioners and concerned authorities working in food companies to boost up their businesses and performances.

\section{Literature Review}

Creative agriculture has significant importance for food companies particularly for the process of creation of innovative products based on available natural mixed with biochemical materials (Abdelaal et al., 2020). Creative agriculture is not just about to harvest crops and grow again new crops but besides growing crops it allows for the creation of new innovative products based on those crops mixed with biochemical or without biochemical. According to the present study, creative agriculture is beneficial for food providing companies, especially in Thailand. Creative agriculture is a set of process or it is a complete system by following which food companies 
brings innovation in their production as well as increase their business gains (Vallera \& Bodzin, 2020). Hence, the present study has illustrated different factors of a creative agriculture system to know how these factors affect on local product promotion for food companies. According to the present study customers' satisfaction depends upon foodservice quality and innovation in production. It means food companies wishing to acquire a higher level of their customers' satisfaction, are need to produce great foodservice qualities before and then bring innovation in the production of their products. Moreover, local product promotion for a food company is only possible when it already has a good level of its customers' satisfaction (Jiang \& Liang, 2019; Kanu \& Ihechu, 2019; Othman, Harun, De Almeida, \& Sadq, 2020). Without customers' satisfaction, it is nearly impossible for food companies to have local product promotion. Hence the relationship between these factors is illustrated in Figure 2.

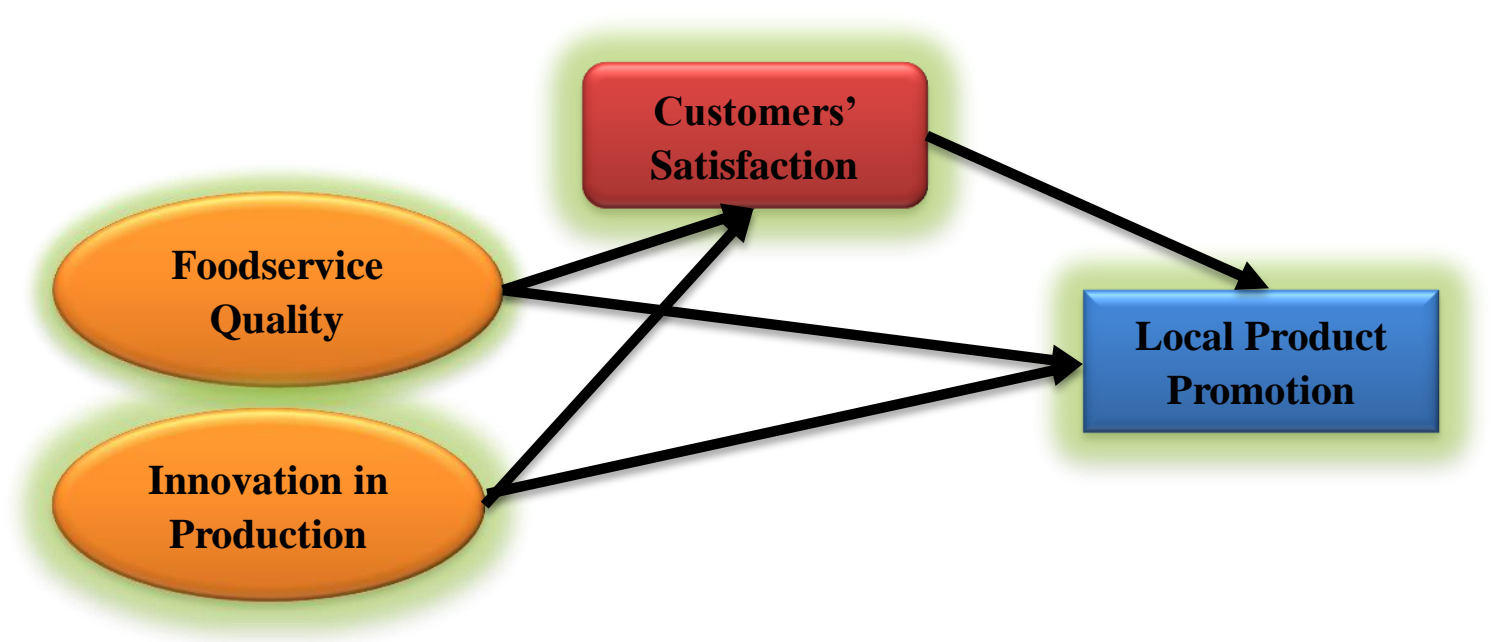

Figure 2. The theoretical framework of the present study illustrating a relationship between foodservice quality, innovation in production, customers' satisfaction, and local product promotion

\subsection{Food Service Quality and Local Product Promotion}

Foodservice quality is an evaluation of how well a delivered service satisfies the consumer's expectations (Saad et al., 2020). Foodservice quality is compulsory for many business operations such as for the improvement of a company's service, better assessment of the end consumer satisfaction, quick identification of issues, and local product promotion. Food producing companies' business is directly connected with their service quality (Bakır, Akan, \& Atalik, 2020; Keho, 2019). If the companies can successfully provide quality services to their food consumers particularly to the end consumers, it increases the promotion of food products locally. While unsatisfactory service quality always brings hurdles for business gains for any food supplying company. Therefore, a foodservice quality has significant importance for local product promotion. According to the previous studies, food supplying companies expending a low budget for the maintenance and adjustment of their foodservice qualities are unable to enhance their foodservice quality due to which they have to face business problems. Whereas food supplying companies with the proper budget allocation to make their foodservice quality better than present condition, always earn more profit by capturing more audience and their satisfaction as well (Langa \& Govender, 2019; Tipmontian, Alcover, \& Rajmohan, 2020). According to the present study, better foodservice quality along with quality food that apparently has a good shape, gloss, size, color, and consistency, while flavor and texture-wise it should meet federal grade standards and internally with proper physical, chemical, and microbial properties, is cause for the better local product promotion for a food supplying company. However, companies with digital marketing also remain successful to meet the target of their local product promotion. Whereas foodservice quality has a greater impact on local product promotion (Bennett et al., 2020). Therefore, with better foodservice quality, food supplying companies earn more local product promotion while a company with unsatisfactory foodservice quality has to face struggles and issues not only to meet its business perspectives but it also remains fail to capture local product promotion for its products. Hence, it is capsulized that; 
H1: Foodservice quality has positive effects on product promotion.

\subsection{Innovation in Production and Local Product Promotion}

Innovation in production means continuous radical or incremental improvement of present production methods or systems in the concept of productivity, speed, flexibility, cost, quality, and promotion (Pei et al., 2020). According to the present study, innovation in production for food companies particularly from Thailand is very important especially for their local product promotion. Innovation in production brings positive changes specifically to the business perspective of a food company (Bellucci, Bini, \& Giunta, 2020). Because food companies with more innovation in production processes earn more revenue as compared with those food companies which run their business in custom manners and don't spend their budget for innovation in production. Initially, such food companies have to face business losses and at last, they being to suffer for competency with their competitors, as a result, they become bankrupt or stop their business. Hence, innovation in production has significant importance. According to the previous studies, innovation in production promises for goodwill as well as notable business gains for a food company (Casais, Fernandes, \& Sarmento, 2020). The present study has explored that innovation in production has a significant influence on local product promotion of food companies in Thailand. The innovation in production brings positive changes in the production of food for a food company and the company becomes able to offer a variety of foods with multiple flavor and flexibilities both in taste and price which help to capture more audiences. Moreover, innovation in production cause for utilization of available raw material which results in more gains and profits for a food company (May \& Guenther, 2020). Hence, Innovation in production is promising for a food company for its local product promotion. Therefore, an increased value of innovation in production increases local product promotion for a food company, especially in Thailand. While lower values of innovation in production for a food company not only decrease its local product promotion but also bring harmful results in the business perspective for the company. Hence, it is hypothesized that;

H2: Innovation in production has a positive effect on local product promotion.

\subsection{Food Service Quality and Customer Satisfaction}

For a food company, customers' satisfaction has a central position because customers' satisfaction determines whether the company product and its services are as per the required standard (Mahafzah, Aljawarneh, Alomari, Altahat, \& Alomari, 2020). Foodservice quality and food quality both are very essential and important for the business of any food company. Although there are many factors that involve in the identification of customers' satisfaction, however, foodservice quality is more significant among all the other factors. Customers never satisfy with poor a foodservice quality. No matter a food company is producing quality food if it fails to provide quality service to its consumers or customers, there will be a decrease in its business (Ballco \& Gracia, 2020). Therefore, a foodservice quality is mandatory for a food company not only to increase its business but also for its customers' satisfaction that also ultimately adds values for the business of the company. According to the previous studies a food company with quality food and service quality has certain effects on its customers' satisfaction. Moreover, the customers' satisfaction has an absolute effect on customers' retention. Therefore, for business success for a food company, particularly in Thailand, customers' satisfaction is necessary by providing high quality services to the customers. Hence, to meet business advantages, a good relationship between a food company and its customers through a better foodservice quality is compulsory (Mahafzah et al., 2020). Otherwise, food companies with a lower foodservice quality cannot earn their customer satisfaction which is not a good sign for the companies, particularly from a business perspective. According to the present study, better service for food can efficiently change up the mind of customers to consume products of a company more than they wish for. In this way, satisfied customers regularly buy from a good foodservice quality which causes for good business for the company. Hence, the increased value of foodservice quality increases the level of customers' satisfaction (Saad et al., 2020). While with the poor foodservice quality of a food company, its customers never satisfied instead they change their mind to buy from another available source that can offer better a foodservice quality. Hence, it is encapsulated that;

H3: Foodservice quality has positive effects on customer satisfaction.

\subsection{Innovation in Production and Customer Satisfaction}

The creation of new products, alteration in already established products, with the use of fresh material and new components, is called innovation in production (Migliore, Oberti, \& Talamo, 2020). Innovation in production for food companies is to create a new product based on available raw material or already established food to meet customers' satisfaction and business gains. According to the present study innovation in production has significant importance for customer satisfaction. However, innovation in production is necessary not only for customers' 
satisfaction but also required to make a new product, to increase established products' quality and for the improvement of the general performance of a food company. According to the previous studies innovation in production assures every business feature for a company (Garina, Kuznetsov, Romanovskaya, Kuznetsova, \& Kornilov, 2020). However, a food company innovating its products on many levels is quite able to gain the required business benchmark within a limited time. Because such companies successfully attract more customers. Innovation in the production process includes an increase in productivity, establish a brand image, discover new markets, acquire finance, and win a competition. And with all these qualities a food company is fully capable to get customers satisfaction. Hence, more increment in innovation in production for a food company promises for an increased level of customers' satisfaction. While the poor or low innovation in the production unit for any food company makes it fail to earn customers' satisfaction. Hence, it is enclosed that;

H4: Innovation in production has positive effects on customers' satisfaction.

\subsection{Customers' Satisfaction and Local Product Promotion}

According to the present study customer satisfaction for any food company particularly in Thailand has significant importance. Because without customers' satisfaction it is quite difficult to achieve not only a business perspective but also to maintain the quality and performance of a food company (Purwanto et al., 2020). In the present study, it is observed that customers' satisfaction is mandatory for a food company for its local product promotion. Local product promotion means a good perception and consumption ratio among the customers of a product or multiple products created by a food company. Hence, local product promotion among customers is only possible when consumers of that product are well satisfied with the taste, size, shape, appearance, properties of biochemical materials, and physical measures of the product. When all the ingredients are mixed as that can make a delicious taste for every consumer of the product, such a product easily earns customers' satisfaction. With an increased value of customers' satisfaction, a food company can easily increase its local product promotion (Orji, Oyenuga, \& Ahungwa, 2020). It is often noted that a food company with a lower level of customers' satisfaction hardly be successful for its local product promotion. Even it doesn't matter if the food company has created a local product with high quality if it has not achieved the level of its customers' satisfaction, such a product will also not be promising for more business gains for the company. Hence, a food company with an increased value of customers' satisfaction can increase its local product promotion. While a food company with minimum or poor level of its customers' satisfaction will not be able to increase its local product promotion. Hence, it is confined that;

H5: Customers' satisfaction has positive effects on local product promotion.

H6: Customers' satisfaction mediates between the relationship foodservice quality and local product promotion.

H7: Customers' satisfaction mediates between the relationship innovation in production and local product promotion.

\section{Research Methodology}

Initially, the population of the present study was selected based on the nature of this study. The population of the present study was the food engineers working with different food companies in Thailand. Hence, in the beginning, 300 size of the population was adopted because this sample size is considered as a satisfactory study size among most of the researchers. Hence, 300 food engineers were the respondents of the present study. Therefore, a list of contact information of the respondents of the present study was created. Then, the area cluster sampling approach was chosen for the present study because this approach is the best possible option for this study which is just according to the nature of the study also. Moreover, for a widespread area, area cluster sampling is a wise selection form any researcher. Because this approach is the best suit for a widespread region.

Along with the selection of area cluster sampling, the quantitative research method was opted over mixed and qualitative methods. Both qualitative and mixed methods approaches were not the best suit for the present study, hence, the quantitative research method approach was selected because this approach is just according to the nature of the present study. After the selection of the research method, a questionnaire was designed comprised of two main sections. In the first section of the questionnaire, the food engineers which are the respondents of the present study were asked to answer the demographic questions such as their name, age, gender, job experience, job position, and some other related questions. While the second section of the questionnaire consisted of the questions related to the key variables of the present study such as food service quality, innovation in production, customer satisfaction, and local product promotion.

After the preparation of the questionnaire, questions based on a 7-point Likert scale starting from "1" as "Strongly Disagree" to "7" as "Strongly Agree" were prepared for the accomplishment of end results of the present study. It 
was decided to deliver copies of the questionnaire along with the Likert scale-based questions and a description of the purposes of the present study. First of all, it was ensured to the respondents that feedback received from them will be remain confidential and will not be used for any other secondary purposes besides the primary objectives of the present study. Moreover, the respondents were requested to be honest and neutral while recording their answers for the questionnaire.

For the distribution of the questionnaire, the national postal service of Thailand was used. Hence, each respondent of the present study was individually contacted via his/her postal address and copies of the questionnaire delivered to them. After 8 days of the delivery of the copies of the questionnaire among the respondents, 70 responses received. Hence it was decided to contact again with the rest respondents as a reminder. After 15 more days after the reminder, more 140 responses received. 25 responses from the total received 210 responses, were excluded because these 25 responses were partially filled. Hence, a statistical software PLS was used for the rest of 185 responses to obtain data analysis from this primary data. Data analysis finalized the end results of the present study. All the measures and scales were adopted from the previous studies.

\section{Data Analysis}

This study measured food service quality with the help of five items, however, two items were deleted due to low factor loadings. Innovation in production was measured through four items and two were deleted. Customer satisfaction was measured through seven items and two were deleted. Finally, local product promotion was measured through six items. Confirmatory factor analysis (CFA) was used to assess the factor loadings of all these items (Dahri, Hameed, Nawaz, Sami, \& Bux Shah, 2019; Hair Jr, Sarstedt, Hopkins, \& Kuppelwieser, 2014; Zahra, Hameed, Fiaz, $\&$ Basheer, 2019). Table 1 shows the factor loadings and Figure 3 shows the CFA. All the factor loadings are above 0.7 , except one item.

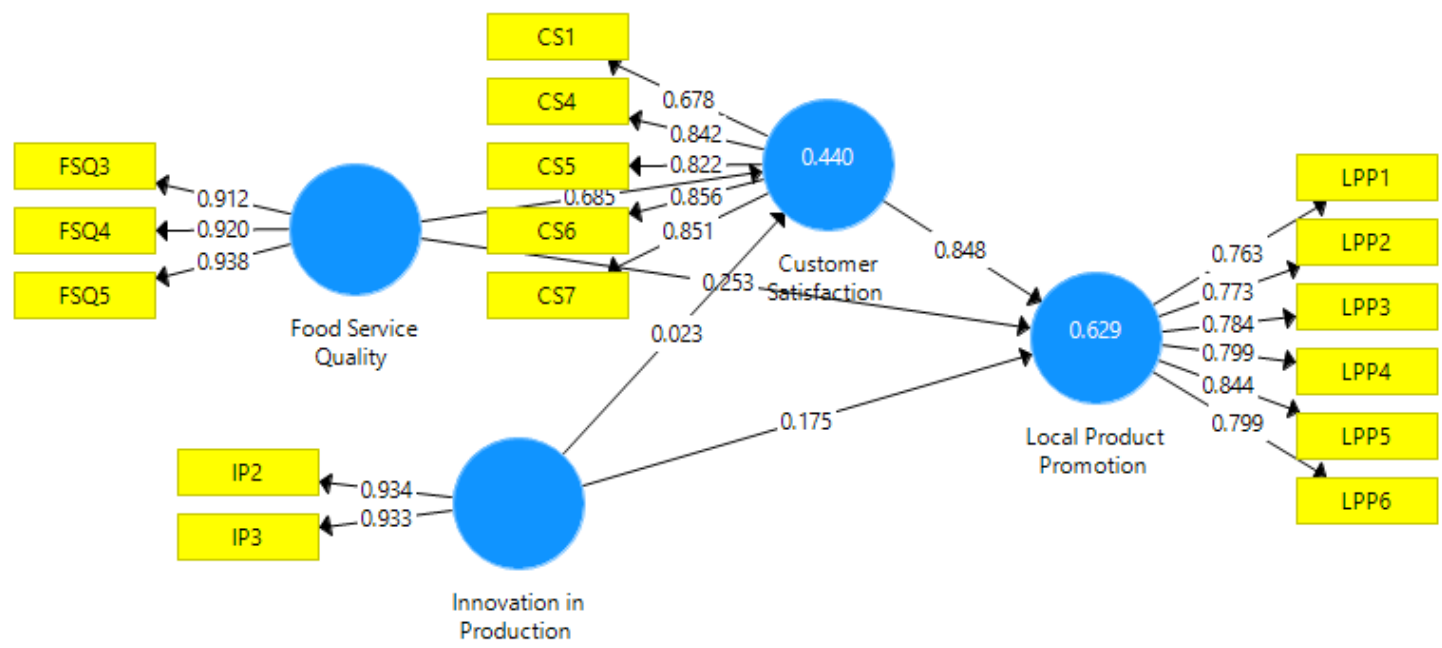

Figure 3. Measurement model

Table 1. Factor loadings

\begin{tabular}{lcccc}
\hline & $\begin{array}{c}\text { Customer } \\
\text { Satisfaction }\end{array}$ & $\begin{array}{c}\text { Food } \\
\text { Service } \\
\text { Quality }\end{array}$ & $\begin{array}{c}\text { Innovation } \\
\text { in } \\
\text { Production }\end{array}$ & $\begin{array}{c}\text { Local } \\
\text { Product } \\
\text { Promotion }\end{array}$ \\
\hline CS1 & 0.678 & & & \\
CS4 & 0.842 & & & \\
CS5 & 0.822 & & & \\
CS6 & 0.856 & & & \\
CS7 & 0.851 & & & \\
FSQ3 & & 0.912 & &
\end{tabular}




\begin{tabular}{|c|c|c|c|}
\hline FSQ4 & 0.92 & & \\
\hline FSQ5 & 0.938 & & \\
\hline IP2 & & 0.934 & \\
\hline IP3 & & 0.933 & \\
\hline LPP1 & & & 0.763 \\
\hline LPP2 & & & 0.773 \\
\hline LPP3 & & & 0.784 \\
\hline LPP4 & & & 0.799 \\
\hline LPP5 & & & 0.844 \\
\hline LPP6 & & & 0.799 \\
\hline
\end{tabular}

By using CFA, this study examined composite reliability (CR) and average variance extracted (AVE) which is shown in Table 2. Food service quality has CR and AVE 0.946 and 0.853 , respectively. Innovation in production has CR and AVE 0.931 and 0.871. Customer satisfaction has $0.906 \mathrm{CR}$ value and AVE 0.66. Finally, local product promotion has CR and AVE 0.911 and 0.631. All these values are given in Table 2. Discriminant validity is achieved through cross-loadings as shown in Table 3.

Table 2. Alpha, CR and AVE

\begin{tabular}{lcccc}
\hline & $\begin{array}{c}\text { Cronbach's } \\
\text { Alpha }\end{array}$ & rho_A & $\begin{array}{c}\text { Composite } \\
\text { Reliability }\end{array}$ & (AVE) \\
\hline Customer Satisfaction & 0.869 & 0.867 & 0.906 & 0.66 \\
Food Service Quality & 0.914 & 0.916 & 0.946 & 0.853 \\
Innovation in Production & 0.852 & 0.852 & 0.931 & 0.871 \\
Local Product Promotion & 0.883 & 0.886 & 0.911 & 0.631 \\
\hline
\end{tabular}

Table 3. Cross-Loadings

\begin{tabular}{lcccc}
\hline & $\begin{array}{c}\text { Customer } \\
\text { Satisfaction }\end{array}$ & $\begin{array}{c}\text { Food } \\
\text { Service } \\
\text { Quality }\end{array}$ & $\begin{array}{c}\text { Innovation } \\
\text { in } \\
\text { Production }\end{array}$ & $\begin{array}{c}\text { Local } \\
\text { Product } \\
\text { Promotion }\end{array}$ \\
\hline CS1 & 0.878 & 0.714 & 0.821 & 0.45 \\
CS4 & 0.842 & 0.432 & 0.402 & 0.678 \\
CS5 & 0.822 & 0.418 & 0.412 & 0.708 \\
CS6 & 0.856 & 0.43 & 0.416 & 0.689 \\
CS7 & 0.851 & 0.415 & 0.388 & 0.68 \\
FSQ3 & 0.602 & 0.912 & 0.894 & 0.436 \\
FSQ4 & 0.577 & 0.92 & 0.892 & 0.431 \\
FSQ5 & 0.656 & 0.938 & 0.816 & 0.444 \\
IP2 & 0.586 & 0.876 & 0.934 & 0.424 \\
IP3 & 0.57 & 0.874 & 0.933 & 0.439 \\
LPP1 & 0.754 & 0.487 & 0.475 & 0.763 \\
LPP2 & 0.577 & 0.327 & 0.333 & 0.773 \\
LPP3 & 0.594 & 0.362 & 0.347 & 0.784 \\
LPP4 & 0.615 & 0.379 & 0.38 & 0.799 \\
LPP5 & 0.603 & 0.341 & 0.313 & 0.844 \\
LPP6 & 0.569 & 0.322 & 0.32 & 0.799 \\
\hline
\end{tabular}


PLS structural model given in Figure 4 is the best recommended process to test the hypotheses (Hair, Hollingsworth, Randolph, \& Chong, 2017; Hair, Sarstedt, Pieper, \& Ringle, 2012; Henseler, Ringle, \& Sinkovics, 2009; Lee, 2019; Li \& Wang, 2019). The direct effect of food service quality was examined on customer satisfaction and local product promotion. The direct effect of customer satisfaction was examined on local product promotion. Innovation in production was examined on customer satisfaction and local product development. Results are given in Table 4 which shows that both food service quality and innovation in production has positive effect on customer satisfaction and local product promotion.

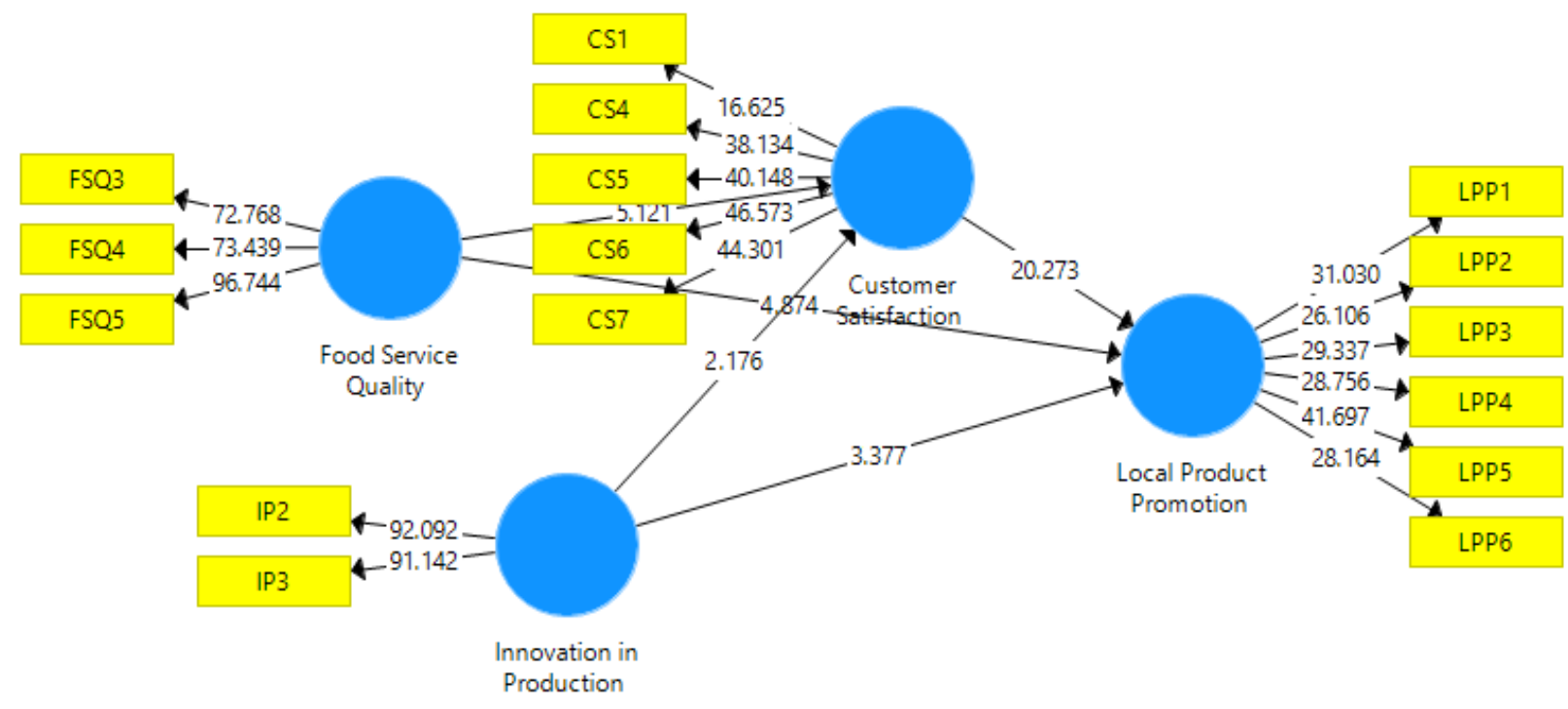

Figure 4. Structural model

Table 4. Direct effect results

\begin{tabular}{lccccc}
\hline & $\begin{array}{c}\text { Original } \\
\text { Sample } \\
(\mathbf{O})\end{array}$ & $\begin{array}{c}\text { Sample } \\
\text { Mean (M) }\end{array}$ & $\begin{array}{c}\text { Standard } \\
\text { Deviation } \\
(\text { STDEV) }\end{array}$ & $\begin{array}{c}\text { T Statistics } \\
(\mid \mathbf{O} / \text { STDEV })\end{array}$ & $\begin{array}{c}\text { P } \\
\text { Values }\end{array}$ \\
\hline $\begin{array}{l}\text { Customer Satisfaction -> Local Product } \\
\text { Promotion }\end{array}$ & 0.848 & 0.848 & 0.042 & 20.273 & 0 \\
$\begin{array}{l}\text { Food Service Quality -> Customer } \\
\text { Satisfaction }\end{array}$ & 0.685 & 0.681 & 0.134 & 5.121 & 0 \\
$\begin{array}{l}\text { Food Service Quality -> Local Product } \\
\text { Promotion }\end{array}$ & 0.253 & 0.264 & 4.135 & 4.874 & 0 \\
$\begin{array}{l}\text { Innovation in Production -> Customer } \\
\text { Satisfaction }\end{array}$ & 0.023 & 0.018 & 0.011 & 2.176 & 0.039 \\
$\begin{array}{l}\text { Innovation in Production -> Local Product } \\
\text { Promotion }\end{array}$ & 0.175 & 0.185 & 0.052 & 3.377 & 0.001 \\
\hline
\end{tabular}

This study examined the mediation effect of customer satisfaction between food service quality and local product promotion. Moreover, the indirect effect was examined between innovation in production and local product promotion. Results in Table 5 and Figure 5 shows that indirect effect of customer satisfaction between food service quality and local product promotion is significant. 
Table 5. Indirect effect results

\begin{tabular}{|c|c|c|c|c|c|}
\hline & $\begin{array}{c}\text { Original } \\
\text { Sample } \\
(0)\end{array}$ & $\begin{array}{c}\text { Sample } \\
\text { Mean } \\
\text { (M) }\end{array}$ & $\begin{array}{l}\text { Standard } \\
\text { Deviation } \\
\text { (STDEV) }\end{array}$ & $\begin{array}{c}\text { T Statistics } \\
(\mid \text { O/STDEV|) }\end{array}$ & $\begin{array}{c}\mathbf{P} \\
\text { Values }\end{array}$ \\
\hline $\begin{array}{l}\text { Food Service Quality -> Customer } \\
\text { Satisfaction -> Local Product Promotion } \\
\text { Innovation in Production -> Customer }\end{array}$ & 0.581 & .578 & 0.121 & 4.787 & 0 \\
\hline Satisfaction -> Local Product Promotion & -0.02 & -0.016 & 0.113 & 0.174 & 0.862 \\
\hline
\end{tabular}

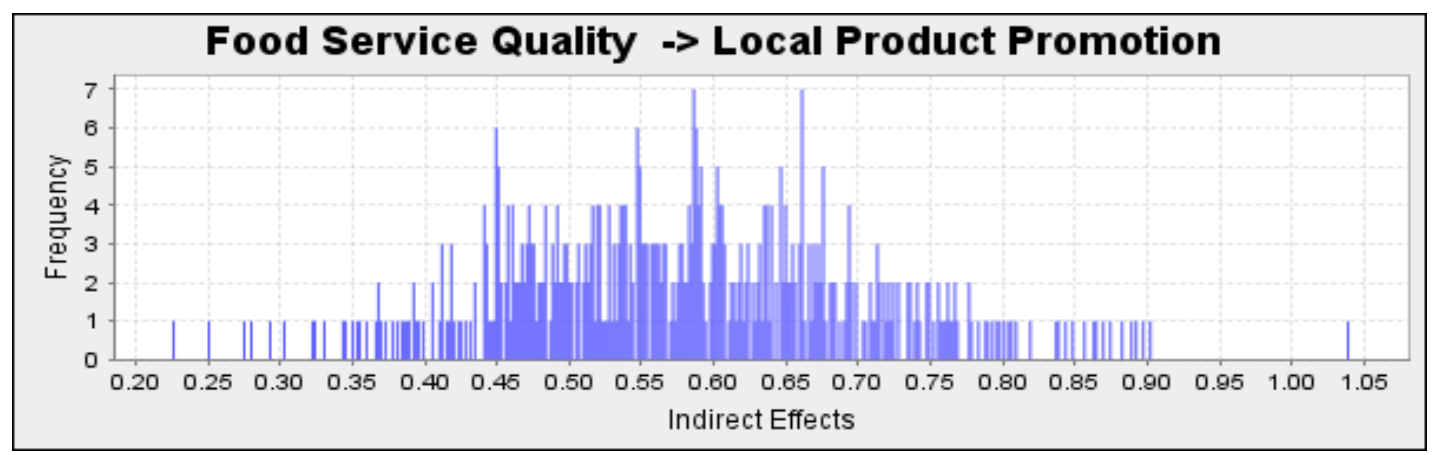

Figure 5. Indirect effect histogram: Food service quality -> Customer satisfaction -> Local product promotion

\section{Discussion}

According to the first hypothesis of the present study, food service quality has positive effects on product promotion. According to a previous study, food companies with poor food service qualities hardly be able to achieve business gains. Moreover, food companies spending more budget on their service qualities gain more business performance (Loukil, 2020; Rezvani \& Fathollahzadeh, 2020). The second hypothesis of the present study describes that; innovation in production has a positive effect on local product promotion. Companies particularly related to food business in Thailand, who are interested in the creation of new products based on available raw material, successfully meet the required level of their local product promotion (Muslim, Sinaga, Bainus, \& Darmawan, 2020). Local product promotion for a food company is a basic issue due to the decreased value of local product promotion for that food company hardly be able to achieve its business performance. The third hypothesis of the present study tells that; a foodservice quality has positive effects on customers' satisfaction. It is obvious that to achieve customers' satisfaction it is necessary to provide them better quality food hence they can be pleased with the taste and quality of food for which they spend their money. Hence, customers more happily and easily spend their money if the service quality of the food is quicker and more reliable. Therefore, foodservice quality has a direct impact on customer satisfaction. According to the fourth hypothesis of the present study; innovation in production has positive effects on customer satisfaction. If the customers find often an opportunity to taste something different and delicious at an affordable price, it makes them more satisfied with the food product providing company. Hence, bringing innovation in food varieties and products causes for more customer satisfaction. The fifth hypothesis of the present study is; customer satisfaction has positive effects on local product promotion. Food companies that have a good reputation among their customers can easily achieve the targets for their local product promotion (Shin, 2020). Customers' satisfaction for a food company is like a reward that works positively for its local product promotion. The last two hypotheses of the present study describe; customer satisfaction mediates between the relationship foodservice quality and local product promotion and customer satisfaction mediates between the relationship innovation in production and local product promotion. This means customer satisfaction has central importance for theoretical as well as the practical beneficiaries of the present study.

\section{Conclusion}

Increased value of customers' satisfaction helps food companies for their local product promotion created by them. Moreover, by increasing food service quality it possible for the food companies to promote easily their local products in Thailand, to earn more satisfaction from their customers. Furthermore, according to the results of the present study, 
it is explored that innovation in production also helps food companies to acquire more customers' satisfaction. Bothe the foodservice quality and innovation in production have indirectly positive effects on local product promotion. It is observed that food companies particularly need to focus on quality food production. Moreover, it is also noticed that food companies allocate comparatively low budgets for the innovation of products. Hence, it is highly recommended to take steps to increase the budget so that creation of new products is easily possible. Furthermore, the food department must have to collaborate with food-producing companies for more safety and quality assurances. Moreover, the present study assists food companies particularly in Thailand to produces more business gains and performance.

\section{References}

Abdelaal, K. A., EL-Maghraby, L. M., Elansary, H., Hafez, Y. M., Ibrahim, E. I., El-Banna, M., . . Elkelish, A. (2020). Treatment of sweet pepper with stress tolerance-inducing compounds alleviates salinity stress oxidative damage by mediating the physio-biochemical activities and antioxidant systems. Agronomy, 10(1), 26.

Bakır, M., Akan, S., \& Atalik, O. (2020). An Evaluation for Long-Haul Low-Cost Carriers Using User-Generated Content: The Impact of Perceived Service Quality on Value for Money. Handbook of Research on Social Media Applications for the Tourism and Hospitality Sector (pp. 231-251). IGI Global.

Ballco, P., \& Gracia, A. (2020). Do market prices correspond with consumer demands? Combining market valuation and consumer utility for extra virgin olive oil quality attributes in a traditional producing country. Journal of Retailing and Consumer Services, 53, 101999.

Bellucci, M., Bini, L., \& Giunta, F. (2020). Implementing environmental sustainability engagement into business: sustainability management, innovation, and sustainable business models. Innovation Strategies in Environmental Science (pp. 107-143). Elsevier.

Bennett, R., Zorbas, C., Huse, O., Peeters, A., Cameron, A. J., Sacks, G., \& Backholer, K. (2020). Prevalence of healthy and unhealthy food and beverage price promotions and their potential influence on shopper purchasing behaviour: A systematic review of the literature. Obesity Reviews, 21(1), e12948.

Burani, N., \& Mantovani, A. (2020). Non-linear pricing and conscious consumption. International Journal of Industrial Organization, 68, 102549.

Casais, B., Fernandes, J., \& Sarmento, M. (2020). Tourism innovation through relationship marketing and value co-creation: A study on peer-to-peer online platforms for sharing accommodation. Journal of Hospitality and Tourism Management, 42, 51-57.

Dahri, A. S., Hameed, W. U., Nawaz, M., Sami, A., \& Bux Shah, S. K. (2019). Nurses' Job Satisfaction is Burned out by their Leaders and Stress. Journal of Managerial Sciences, 13(2).

Debnath, S. (2020). Flax Fibre Extraction to Fashion Products Leading Towards Sustainable Goals. The UN Sustainable Development Goals for the Textile and Fashion Industry (pp. 47-57). Springer.

F. Hair Jr, J., Sarstedt, M., Hopkins, L., \& G. Kuppelwieser, V. (2014). Partial least squares structural equation modeling (PLS-SEM) An emerging tool in business research. European Business Review, 26(2), 106-121.

Garina, E. P., Kuznetsov, V. P., Romanovskaya, E. V., Kuznetsova, S. N., \& Kornilov, D. A. (2020). Formation of the Production System Elements in the Enterprise of the Industry Through the Integration of Production Systems and Product Creation Systems. Growth Poles of the Global Economy: Emergence, Changes and Future Perspectives (pp. 441-451). Springer.

Hair, J., Hollingsworth, C. L., Randolph, A. B., \& Chong, A. Y. L. (2017). An updated and expanded assessment of PLS-SEM in information systems research. Industrial Management \& Data Systems, 117(3), 442-458.

Hair, J. F., Sarstedt, M., Pieper, T. M., \& Ringle, C. M. (2012). The use of partial least squares structural equation modeling in strategic management research: a review of past practices and recommendations for future applications. Long range planning, 45(5-6), 320-340.

Henseler, J., Ringle, C. M., \& Sinkovics, R. R. (2009). The use of partial least squares path modeling in international marketing. New challenges to international marketing (pp. 277-319). Emerald Group Publishing Limited.

Jiang, H., \& Liang, T. (2019). Investigate airport service quality-a case study of airports in Shanghai. International Journal of Business, Economics and Management, 6(2), 61-75.

Kanu, C. E., \& Ihechu, I. P. (2019). Influence of employees' job satisfaction and performance on health care delivery 
in Abia State University Teaching Hospital, Nigeria. Global Journal of Social Sciences Studies, 5(2), 88-104.

Keho, Y. (2019). Revisiting the exports and economic growth Nexus: Rolling window cointegration and causality evidence from Cote d'Ivoire, Malaysia, Pakistan and South Africa. Asian Journal of Economics and Empirical Research, 6(1), 27-35.

Langa, M., \& Govender, K. K. (2019). The need for agile relationship lending between small business and banks, towards a more engaged relationship: A case study in Khayelitsha, South Africa. Asian Business Research Journal, 4(1), 29-34.

Lee, J.-J. (2019). The study on the correlation between wholesale price and trading volume in Taiwan Milkfish Market. Asian Journal of Economic Modelling, 7(2), 73-81.

Li, M., Zhang, Y., Xu, M., He, L., Liu, L., \& Tang, Q. (2020). China Eco-Wisdom: A Review of Sustainability of Agricultural Heritage Systems on Aquatic-Ecological Conservation. Sustainability, 12(1), 60.

Li, P., \& Wang, Z. (2019). Household leverage and stock market investment decisions. Asian Economic and Financial Review, 9(1), 30-41.

Loukil, K. (2020). Intellectual property rights, human capital and innovation in emerging and developing countries. Journal of Social Economics Research, 7(1), 35-41.

Mahafzah, A. G., Aljawarneh, N. M., Alomari, K. A. K., Altahat, S., \& Alomari, Z. S. (2020). Impact of customer relationship management on food and beverage service quality: The mediating role of employees satisfaction. Humanities \& Social Sciences Reviews, 8(2), 222-230.

May, N., \& Guenther, E. (2020). Shared benefit by Material Flow Cost Accounting in the food supply chain-The case of berry pomace as upcycled by-product of a black currant juice production. Journal of Cleaner Production, $245,118946$.

Migliore, M., Oberti, I., \& Talamo, C. (2020). Circular Economy and Recycling of Pre-consumer Scraps in the Construction Sector. Cross-Sectoral Exchange Strategies for the Production of Eco-Innovative Building Products. Regeneration of the Built Environment from a Circular Economy Perspective (pp. 217-228). Springer.

Muslim, A. R., Sinaga, O., Bainus, A., \& Darmawan, W. B. (2020). Implementation of Rural Development Policy in Thailand through the One Tambon One Product (OTOP) Movement. Systematic Reviews in Pharmacy, 11(1), 585-587.

Orji, M. G., Oyenuga, M., \& Ahungwa, A. I. (2020). Effects of Sales Promotion on Consummer Buying Behavior of Food Seasoning Among Nigerian House Holds: A Case Study Of Nestle Maggi Naijapot. Budapest International Research and Critics Institute (BIRCI-Journal): Humanities and Social Sciences, 3(1), 134-149.

Othman, B. A., Harun, A., De Almeida, N. M., \& Sadq, Z. M. (2020). The effects on customer satisfaction and customer loyalty by integrating marketing communication and after sale service into the traditional marketing mix model of Umrah travel services in Malaysia. Journal of Islamic Marketing.

Pei, F., Sun, L., Fang, Y., Yang, W., Ma, G., Ma, N., \& Hu, Q. (2020). Behavioral Changes in Glutenin Macropolymer Fermented by Lactobacillus plantarum LB-1 to Promote the Rheological and Gas Production Properties of Dough. Journal of Agricultural and Food Chemistry, 68(11), 3585-3593.

Purwanto, A., Putri, R. S., Ahmad, A. H., Asbari, M., Bernarto, I., Santoso, P. B., \& Sihite, O. B. (2020). The Effect of Implementation Integrated Management System ISO 9001, ISO 14001, ISO 22000 and ISO 45001 on Indonesian Food Industries Performance. TEST Engineering \& Management, 82, 14069.

Rampa, F., Lammers, E., Linnemann, A., Schoustra, S., \& de Winter, D. (2020). Pathways to improved food and nutrition security of the poor: The promise of African indigenous foods and technologies.

Rezvani, M., \& Fathollahzadeh, Z. (2020). The impact of entrepreneurial marketing on innovative marketing performance in small-and medium-sized companies. Journal of Strategic Marketing, 28(2), 136-148.

Saad, M., AbuKhalifeh, A. N., Slamat, S. S., \& TengkuYacob, T. N. F. F. (2020). Assessing the Use of Linear Regression Analysis in Examining Service Quality and Customer Satisfaction Relationship in Premium Casual Restaurants (PCR) in Subang Jaya (Klang Valley) Malaysia. Review of Integrative Business and Economics Research, 9, 369-379.

Shin, Y. H. (2020). Predicting Consumer Intentions Regarding State-branded Food Products in the Grocery and Restaurant Settings: Understanding the Role of Self-Concept. Journal of Quality Assurance in Hospitality \& 
Tourism, 1-16.

Tipmontian, J., Alcover, J. C., \& Rajmohan, M. (2020). Impact of Blockchain Adoption for Safe Food Supply Chain Management through System Dynamics Approach from Management Perspectives in Thailand. Paper presented at the Multidisciplinary Digital Publishing Institute Proceedings.

Vallera, F. L., \& Bodzin, A. M. (2020). Integrating STEM with AgLIT (Agricultural Literacy Through Innovative Technology): The Efficacy of a Project-Based Curriculum for Upper-Primary Students. International Journal of Science and Mathematics Education, 18(3), 419-439.

Zahra, M., Hameed, W. U., Fiaz, M., \& Basheer, M. F. (2019). Information Technology Capability a Tool to Expedite Higher Organizational Performance. UCP Management Review (UCPMR), 3(1), 94-112.

\section{Copyrights}

Copyright for this article is retained by the author(s), with first publication rights granted to the journal.

This is an open-access article distributed under the terms and conditions of the Creative Commons Attribution license (http://creativecommons.org/licenses/by/4.0/). 